\title{
IMPLEMENTASI ALAT PENGUPAS DAN MESIN PARUT KELAPA SEBAGAI UPAYA PENINGKATAN KAPASITAS PRODUKSI MINYAK KELAPA DI IKM SAKRA TIMUR
}

\author{
Yeni Sulastri'1), Ibrahim ${ }^{2}$, Mursal Ghazali3), Nurhayati ${ }^{4)}$ \\ 1)IImu dan Teknologi Pangan, FATEPA, Universitas Mataram, Mataram, NTB, Indonesia \\ 2) Pendidikan Geografi, FKIP, Universitas Muhammadiyah Mataram, Mataram, NTB, Indonesia \\ ${ }^{3)}$ Biologi, FMIPA, Universitas Mataram, Mataram, NTB, Indonesia \\ ${ }^{4)}$ Teknologi Hasil Pertanian, FAPERTA, Universitas Muhammadiyah Mataram, Mataram, NTB, Indonesia \\ Corresponding author: Nurhayati \\ E-mail : nurhayati.faperta.ummat@gmail.com
}

Diterima 07 Desember 2020, Direvisi 18 Januari 2021, Disetujui 19 Januari 2021

\begin{abstract}
ABSTRAK
Alat pengupas kelapa dan parut kelapa untuk IKM Sakra Timur Kabupaten Lombok Timur sangat membantu dalam meningkatkan kapasitas dan mengurangi lama proses produksi minyak kelapa. Proses pengolahan dari buah kelapa utuh akan menghasilkan serabut kelapa dan buah kelapa, selanjutnya akan diperas sehingga menghasilkan santan dan ampas kelapa. Sebelumnya mitra melakukan proses pengupasan secara manual dan menggunakan parang sehingga menguras tenaga, waktu dan berbahaya bagi pekerja, sedangkan pemarutan dilakukan dengan alat pemarut dengan kapasitas kecil. Tujuan dari kegiatan ini adalah untuk mengimplementasikan alat pengupas dengan sistem pedal kaki dan pemarut kelapa berbentuk granat dan pemarut dengan kapasitas yang lebih besar sehingga hasil yang diperoleh lebih banyak dengan waktu yang efisien dan efektif. Metode pelaksanaan yang digunakan adalah kegiatan alih teknologi dan demonstrasi. Tahapan kegiatan meliputi : (i) Persiapan pelaksanaan kegiatan, (ii) Kegiatan alih teknologi, (iii) Evaluasi keberhasilan kegiatan. Kegiatan alih teknologi berupa implementasi penggunaaan alat pengupas dan parut kelapa mampu meningkatkan produktivitas minyak kelapa pada kedua mitra. Model alat pengupas dan parut kelapa mudah dioperasikan, nyaman dalam pengoperasian, menghemat tenaga dan aman dalam pemakaian dengan kapasitas alat pengupas 2 buah per menit dan alat pemarut 6 buah per menit
\end{abstract}

Kata kunci: pengupas; parut; minyak kelapa; sakra timur

\begin{abstract}
The coconut peeler and grated coconut for IKM Sakra Timur, East Lombok Regency, help increase capacity and reduce the length of the coconut oil production process. The processing of whole coconuts will produce coconut fibers and coconut fruit, which will then be pressed to produce coconut milk and coconut pulp. Previously, the partners carried out the peeling process manually and used a cleaver to be draining, time-consuming and dangerous for workers. At the same time, grading was done with a small grater capacity. The purpose of this activity is to implement a peeler with a foot pedal system and a coconut grater in the form of grenades, and a grater with a larger capacity so that more results can be obtained efficiently and effectively. The implementation method used is technology transfer and demonstration activities. The stages of activities include (i) Preparation for the implementation of activities, (ii) Technology transfer activities, (iii) Evaluation of the success of activities. The technology transfer activity in implementing the use of coconut peeler and grated equipment increased the productivity of coconut oil for both partners. The coconut peeler and grate model is easy to operate, comfortable in operation, energy-saving, and safe in use with a peeler capacity of 2 pieces per minute and a grater of 5 pieces per minute.
\end{abstract}

Keywords: peeler; grater; coconut oil; east sakra

\section{PENDAHULUAN}

Hampir seluruh masyarakat Indonesia mengenal tanaman kelapa. Karena tanaman tersebut tersebar di seluruh wilayah Indonesia. Berdasarkan data Pusat Penelitian dan Pengembangan Perkebunan (2020) bahwa tanaman kelapa di Indonesia mencapai
3.500 .726 (ha) dan menghasilkan produksi sebanyak 2.992.190 (ton) pada tahun 2019. Produksi kelapa sebagian besar berasal dari perkebunan rakyat yang melibatkan 7,7 juta KK petani. Sebagian petani mengolah kelapa menjadi minyak kelapa 
Salah satu pengolahan minyak kelapa dilakukan di Desa Lepak kecamatan Sakra Timur Kabupaten Lombok Timur. Di Desa tersebut terdapat terdapat dua Industri Kecil Menengah (IKM) yang mengolah kelapa menjadi minyak goreng dan VCO yakni IKM Agro Mulia Lombok dan IKM Tunas Mulia. Keberadaan IKM menjadi bagian penting dalam perekonomian daerah, munculnya berbagai IKM di setiap kecamatan bahkan desa harus mampu memberikan peningkatan daya saing terhadap kuantitas maupun kualitas produk yang dihasilkan (Nurhayati et al., 2021).

Produk minyak kelapa yang dihasilkan oleh kedua IKM memiliki kuantitas dan kualitas yang sangat dipengaruhi oleh teknologi proses pengolahan yang dilakukan. Berdasarkan hasil wawancara dan survey langsung ke lapangan, aplikasi teknologi pengolahan pada kedua mitra masih sangat sederhana. Proses pengolahan dari buah kelapa utuh akan menghasilkan serabut kelapa dan buah kelapa, selanjutnya akan diperas sehingga menghasilkan santan dan ampas kelapa. Sebelumnya mitra melakukan proses pengupasan secara manual dan menggunakan parang sehingga menguras tenaga, waktu dan berbahaya bagi pekerja, sedangkan pemarutan dilakukan dengan alat pemarut dengan kapasitas kecil. Kegiatan pengolahan juga masih dilakukan secara bergotong royong, sehingga membutuhkan pekerja yang lebih banyak. Oleh karena itu diperlukan suatu upaya untuk menjamin keberlangsungan proses pengolahan berjalan secara terus menerus.

Upaya yang dapat dilakukan untuk mengatasi masalah tersebut dapat dilakukan melalui penyediaan alat pengolahan melalui alih teknologi (Karouw et al., 2019). Alih teknologi ini dapat dilakukan melalui pelatihan kepada IKM untuk memfasilitasi penyediaan peralatan pengolahan. Salah satu peralatan pengolahan yang masih sangat sederhana dilakukan adalah pada proses pengupasan sabut kelapa dan pemarutan daging buah kelapa.

Pengupasan sabut kelapa umumnya dilakukan secara tradisional, namun mempunyai beberapa kekurangan seperti kapasitas kerja yang kecil. Pengupasan kelapa membutuhkan waktu sekitar $1-5$ menit dengan upah sebesar Rp 300 sampai Rp 400,- per buah (Putera et al., 2019). Dengan demikian jika dilakukan pengolahan minyak kelapa dengan jumlah yang cukip banyak maka waktu, biaya dan tenaga yang dibutuhkan cukup besar.

Hal yang sama juga terjadi pada proses pemarutan kelapa, umumnya mitra menggunakan parut kelapa manual. Alat parut kelapa manual biasanya terbuat dari plat besi yang memiliki duri kecil yang berada dipermukaan plat (Hardono, 2017). Alat ini sangat sederhana, membutuhkan waktu yang cukup lama hanya untuk memarut satu buah kelapa serta tidak jarang sering terjadi luka ringan. Oleh karena itu, seiring dengan berkembangnya teknologi seperti kondisi sekarang ini, manusia dituntut untuk melakukan suatu inovasi baru yang dapat memudahkan pekerjaan menjadi lebih efisien (Hamdi \& Purkuncoro, 2019).

Berdasarkan identifikasi permasalahan yang telah dijabarkan, maka telah dilakukan kegiatan alih teknologi berupa implementasi alat pengupas kelapa manual tipe pedal kaki dan parut kelapa skala menengah pada IKM pengolah minyak kelapa di Desa Lepak Kecamatan Sakra Timur.

\section{METODE}

Kegiatan ini dilaksanakan pada bulan Oktober-November 2020 dengan lokasi di IKM Sakra Timur yang mengolah minyak goreng kelapa dan Virgin Coconut Oil (VCO). Metode kegiatan yang digunakan adalah metode PRA (Participatory Rural Appraisal) (Ihromi et al., 2020). Metode PRA ini merupakan suatu metode yang melibatkan masyarakat dalam seluruh aspek kegiatan mulai dari perencanaan sampai evaluasi kegiatan (Nurhayati et al., 2020b). Kegiatan pengabdian ini dilakukan dengan melibatkan dua kelompok mitra yaitu Agro Mulia dan Tunas Mulia Agro Mulia dan Tunas Mulia. Kedua kelompok beranggotakan masing - masing sebanyak enam orang. Kegiatan pengabdian ini berlangsung dalam beberapa tahapan kegiatan diantaranya :

a. Persiapan pelaksanaan kegiatan, kegiatan ini diawali dengan konsolidasi dan koordinasi antara tim pengabdian dengan mitra. Konsoliadasi dan Koordinasi berhubungan dengan persiapan kegiatan baik itu penentuan lokasi kegiatan, penetapan waktu kegiatan, alat dan bahan yang digunakan serta jumlah peserta yang terlibat dalam kegiatan ini.

b. Kegiatan alih teknologi berupa demonstrasi pembuatan minyak kelapa serta demplot percobaan terkait efisiensi penggunaan alat pengupas sabut kelapa tipe pedal kaki dan juga alat parut kelapa. Demplot digunakan untuk membandingkan antara penggunaan secara manual atau konvensional dengan penggunaan alih teknologi dengan menghitung kapasitas alat secara langsung(Ghazali et al., 2020). Sebelum dilakukan demonstrasi, terlebih dahulu para mitra diberikan cara pengoperasional dan pemeliharaan alat yang dilakukan oleh teknisi dan tim pelaksana pengabdian. 
c. Evaluasi keberhasilan kegiatan

Keberhasilan kegiatan dilakukan dengan cara mengevaluasi tanggapan yang diberikan oleh mitra seperti tingkat partisipasi dan keseriusan mitra selama kegiatan berlangsung. Selain itu juga dari jawaban - jawaban mitra dari pertanyaan yang diajukan oleh tim pelaksana (Ghazali et al., 2021).

\section{HASIL DAN PEMBAHASAN \\ Persiapan pelaksanaan kegiatan}

Rencana pelaksanaan kegiatan dilakukan secara musyawarah melalui diskusi dengan kedua mitra yakni IKM Tunas Mulia dan Agro Mulia Lombok. Berdasarkan hasil musyawarah bersama maka diputuskan bahwa kegiatan alih teknologi akan dilaksanakan pada hari Minggu 22 November 2020 bertempat di lokasi IKM Agro Mulia Lombok di Dusun Roton Desa Bongkem Desa Lepak Kecamatan Sakra Timur. Kegiatan dilaksanakan oleh kedua mitra IKM beserta masing-masing anggota IKM sehingga jumlah peserta yang terlibat berjumlah 12 orang. Tim pelaksana pengabdian terdiri dari empat orang dosen dan empat orang mahasiswa.

\section{Kegiatan alih teknologi}

Peralatan yang sederhana dan sangat tradisional menjadi permasalahan utama yang dialami oleh sebagian Industri Kecil Menengah (IKM) (Azis et al., 2020). Masalah yang sama dihadapi juga oleh IKM Tunas Mulia dan Agro Mulia Lombok dalam memproduksi minyak kelapa.

Pada kegiatan ini mitra diberikan pelatihan produksi minyak kelapa melalui alih teknologi. Teknologi yang diintroduksi kepada mitra yaitu alat pengupas dan mesin parut kelapa. Pengolahan minyak kelapa baik itu minyak goreng dan VCO yang terdapat di kedua mitra yakni IKM Tunas Mulia dan Agro Mulia Lombok diawali dengan melakukan proses pengupasan sabut kelapa.

Alat pengupas kelapa merupakan suatu alat yang berfungsi untuk memisahkan sabut kelapa dari batok kelapa sehingga lebih aman, efisien, lebih mudah dan menghemat biaya untuk dapat dipergunakan (Kusmayadi, 2019; Pogo, 2015).

Menurut Putera et al., (2019), pengupasan sabut kelapa banyak dilakukan menggunakan alat yang terbuat dari plat besi, alat ini berbentuk linggis dengan tinggi sekitar $80 \mathrm{~cm}$, terdapat bagian tajam yang menghadap keatas. Namun beberda halnya dengan yang diaplikasikan oleh IKM.

Berdasarkan informasi dari pemilik IKM, proses pengupasan sabut kelapa dilakukan secara manual dengan peralatan rumah tangga yang ada seperti menggunakan parang seperti yang disajikan pada Gambar 1. Proses ini cukup menghabiskan banyak waktu, tenaga dan cukup berbahaya karena rentan untuk mengalami kecelakaan kecil.

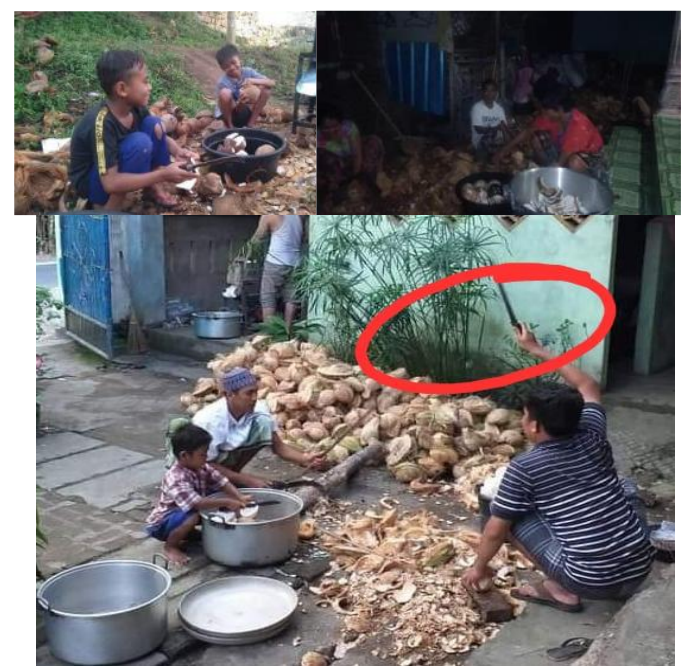

Gambar 1. Proses pengupasan kelapa

Pada kesempatan tersebut, mitra terlebih dahulu diperkenalkan mengenai fungsi dan bagian-bagian alat tersebut. Selanjutnya mitra diberikan penjelasan bagaimana tata cara mengoperasikan alat tersebut sesuai dengan keamanan. Setelah mitra diberikan penjelasan singkat, selanjutnya dilatih mengoperasikan alat tersebut. Alat pengupas kelapa yang diintroduksi ke mitra seperti disajikan pada Gambar 2.

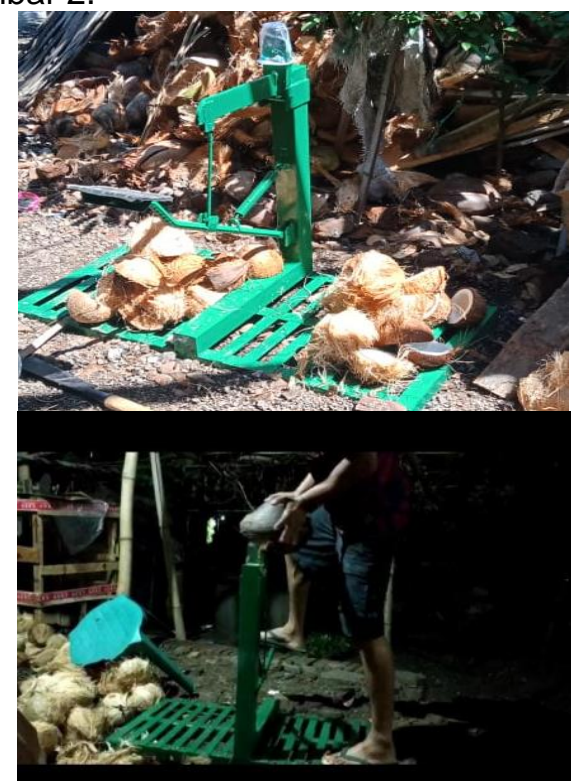

Gambar 2. Alat pengupas kelapa model pedal kaki

Alat pengupas kelapa model pedal ini dirasa cukup efektif dalam pengguaannya Mitra 
merasa sangat terbantu dalam melalukan Alat pengupas kelapa model pedal ini dirasa cukup efektif dalam penggunaannya. Mitra merasa sangat terbantu dalam melakukan proses pengupasan kelapa. Kelapa diletakkan dibagian ujung alat kemudian pedal ditekan sehingga kulit dan sabut kelapa dapat dipisahkan dengan tempurungnya.

Pada demplot percobaan dilakukan perbandingan efisiensi penggunaan alat pengupas kelapa antara pemakaian parang dan penggunaan alat pengupas dengan mengukur kapasitas kerja dari alat yang diimplementasikan. Hasil demplot menunjukkan bahwa penggunaan parang sangat tidak efisien dan memungkinkan terjadinya cedera. Penggunaan parang hanya dapat mengupas kelapa sebanyak 20-30 per jam dibandingkan dengan penggunaan alat yang diintroduksi sebanyak kurang lebih 70-90 buah per jam. Introduksi alat akan dapat menghemat waktu pengerjaan, sehingga produktivitas juga akan semakin tinggi.

Rentetan dari pengolahan minyak kelapa selanjutnya yakni dilakukannya proses pemarutan kelapa. Untuk proses pemarutan kelapa, sebelumnya mitra masih menggunakan alat skala kecil dan bahkan masih menggunakan alat parut manual. Melalui kegiatan ini mitra dibekali dengan keterampilan menggunakan alat pemarut kelapa berskala sedang dengan dua model parut yaitu parut tipe granat dan tipe roll. Parut tipe granat dan tipe roll dapat dilihat pada Gambar 3 dan 4.

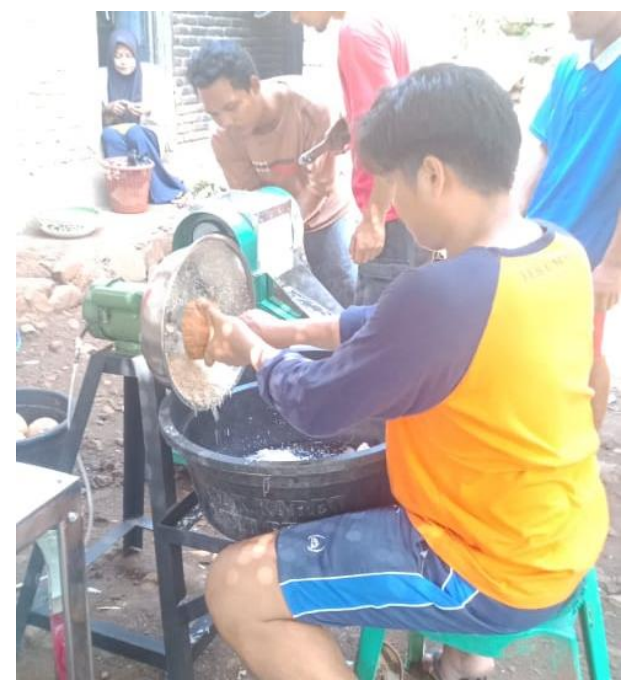

Gambar 3.Mesin parut tipe scrapper (granat)

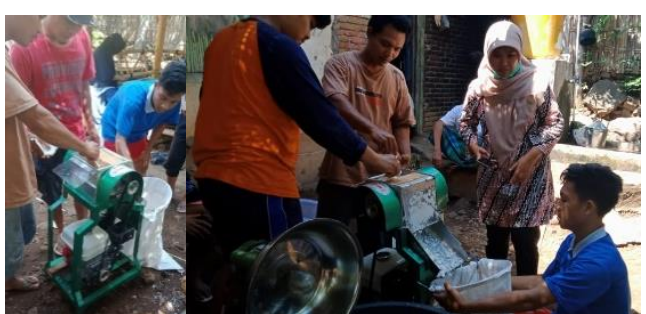

Gambar 4. Mesin Parut tipe roll

Berdasarkan demplot percobaan yang dilakukan kapasitas penggunaan alat berkisar antara 60-80 butir per jam. Apabila dibandingkan dengan penggunaan mesin parut skala kecil yang membutuhkan waktu 30-40 butir setiap jamnya. Bahkan diawal merintis usaha pengolahan minyak kelapa proses pemarutan kelapa dilakukan menggunakan alat parut manual sehingga membutuhkan waktu yang sangat lama dan juga membutuhkan tenaga kerja yang cukup banyak.

\section{Evaluasi keberhasilan kegiatan}

Keberhasilan kegiatan dapat dilakukan dengan observasi secara langsung terhadap pelaksanaan kegiatan (Nurhayati et al., 2020a), melihat respon dan tanggapan serta keterampilan peserta (Sulastri et al., 2018). Secara umum kegiatan pengabdian berupa kegiatan alih teknologi melalui implementasi alat pengupas kelapa model pedal dan mesin parut kelapa tipe roll dan tipe scrapper (granat) berjalan secara lancar dan sangat efektif. Para peserta yang merupakan anggota IKM sangat antusias, respon cukup baik dan bersemangat dalam mengikuti pelatihan yang diberikan oleh tim. Pertanyaan - pertanyaan berupa pemakaian alat yang dilakukan sebelum introduksi dan terkait pemeliharaan alat pun dijawab dengan penuh semangat sesuai dengan penjelasan yang diberikan selama kegiatan berlangsung. Para peserta juga memperlihatkan keterampilannya dalam mengoperasikan alat.

\section{SIMPULAN DAN SARAN}

Kegiatan pengabdian yang telah dilakukan berjalan sukses dan lancer tanpa adanya halangan apapun. Kegiatan ini memberikan penigkatan pengetahuan mitra terhadap fungsi dan bagian alat mesin, selain itu juga meningkatkan keterampilan mitra dalam mengoperasikan alat dan mesin pengoperasian yang diintroduksi. Mitra memiliki keinginan agar produk yang dihasilkan memiliki kualitas yang baik, harga yang menguntungkan dan kompetitif serta memiliki jangkauan pemasaran yang luas.

Kegiatan alih teknologi berupa implementasi penggunaaan alat pengupas dan mesin parut kelapa diharapkan mampu 
meningkatkan produktivitas minyak kelapa baik itu minyak goreng dan VCO pada kedua mitra.

\section{UCAPAN TERIMAKASIH}

Penulis mengucapkan terima kasih atas pembiayaan kegiatan pengabdian kepada masyarakat ini oleh Kementerian Riset dan Teknologi/ Badan Riset dan Inovasi Nasional melalui Program Program Penerapan Teknologi Tepat Guna Kepada Masyarakat Tahun Anggaran 2020.

\section{DAFTAR RUJUKAN}

Azis, R., Akolo, I. R., Pomalingo, Moh. F., \& Staddal, I. (2020). Pengembangan Usaha Minyak Kelapa Tradisional untuk Meningkatkan Pendapatan IKM Desa Posso, Kabupaten Gorontalo Utara. Agrokreatif: Jurnal IImiah Pengabdian kepada Masyarakat, 6(2), 150-158.

https://doi.org/10.29244/agrokreatif.6.2 $.150-158$

Ghazali, M., Kurnianingsih, R., Nurhayati, N., \& Sunarpi, S. (2020). PENDAMPINGAN KELOMPOK TANI "PASIR PUTIH" DALAM MEWUJUDKAN DESA EKAS BUANA SEBAGAI LUMBUNG BIBIT RUMPUT LAUT NUSA TENGGARA BARAT. JMM (Jurnal Masyarakat Mandiri), 4(5), 742-751. https://doi.org/10.31764/jmm.v4i5.295 0

Ghazali, M., Rabbani, R., Sari, M., Rohman, M. H., Nasiruddin, M. H., Suherman, S., \& Nurhayati, N. (2021). Pelatihan Pengolahan Kerupuk Ikan di Desa Ekas Buana Kecamatan Jerowaru Kabupaten Lombok Timur. Jurnal Pengabdian Magister Pendidikan IPA, 4(2), Article 2. https://doi.org/10.29303/jpmpi.v4i2.683

Hamdi, M. I., \& Purkuncoro, A. E. (2019). PERENCANAAN KONSTRUKSI MESIN KUPAS KELAPA MUDA [Tugas_akhir, ITN MALANG]. https://doi.org/10/DAFTAR\%20GAMB AR.pdf

Hardono, J. (2017). RANCANG BANGUN MESIN PEMARUT KELAPA SKALA RUMAH TANGGA BERUKURAN $1 \mathrm{KG}$ PER WAKTU PARUT 9 MENIT DENGAN MENGGUNAKAN MOTOR LISTRIK 100 WATT. Motor Bakar: Jurnal Teknik Mesin, 1(1), Article 1. http://jurnal.umt.ac.id/index.php/mjtm/a rticle/view/185

Ihromi, S., Marianah, M., \& Nurhayati, N. (2020). IbM INOVASI TEKNOLOGI OLAHAN BERBASIS PISANG UNTUK
Volume 4, Nomor 2., April 2021. p-ISSN : 2614-5251 e-ISSN : 2614-526X

PEMBERDAYAAN EKONOMI WANITA TANI DI SEKITAR HUTAN LINDUNG SESAOT DESA PAKUAN KECAMATAN NARMADA. Jurnal Agro Dedikasi Masyarakat (JADM), 1(1), 3036.

Karouw, S., Santosa, B., \& Maskromo, I. (2019). TEKNOLOGI PENGOLAHAN MINYAK KELAPA DAN HASIL IKUTANNYA / Processing Technology of Coconut Oil and Its By Products. Jurnal Penelitian Dan Pengembangan Pertanian, 38(2), 86-95.

https://doi.org/10.21082/jp3.v38n2.201 9.p86-95

Kusmayadi, R. (2019). RANCANG BANGUN ALAT PENGUPAS KULIT KELAPA MUDA SECARA MEKANIS UNTUK INDUSTRI RUMAH TANGGA (HOME INDUSTRI). FAKULTAS PERTANIAN UNIVERSITAS MUHAMMADIYAH MATARAM MATARAM.

Nurhayati, N., Asmawati, A., Ihromi, S., Marianah, M., \& Saputrayadi, A. (2020a). PEMBERDAYAAN EKONOMI MASYARAKAT MELALUI APLIKASI TEKNOLOGI PENGOLAHAN DODOL NANGKA DAN SUSU BIJI NANGKA DI KABUPATEN LOMBOK BARAT. SELAPARANG Jurnal Pengabdian Masyarakat Berkemajuan, 4(1), 522528.

https://doi.org/10.31764/jpmb.v4i1.332 1

Nurhayati, N., Asmawati, A., Ihromi, S., Marianah, M., \& Saputrayadi, A. (2020b). PENYULUHAN GIZI DAN PELATIHAN PENGOLAHAN PRODUK BERBASIS JAGUNG SEBAGAI UPAYA MEMINIMALISIR STUNTING DI DESA LABUAPI KABUPATEN LOMBOK BARAT. JMM (Jurnal Masyarakat Mandiri), 4(5), 806-817. https://doi.org/10.31764/jmm.v4i5.297 3

Nurhayati, N., Sulastri, Y., Ghazali, M., \& Ibrahim, I. (2021). PENYULUHAN CARA PENGOLAHAN PANGAN YANG BAIK UNTUK PERBAIKAN PROSES PRODUKSI DAN MUTU MINYAK KELAPA DI IKM SAKRA TIMUR LOMBOK. JMM (Jurnal Masyarakat Mandiri), 5(1), 152-160. https://doi.org/10.31764/jmm.v5i1.350 2

Pogo, R. (2015). PEMBUATAN MESIN PENGUPAS SABUT KELAPA HASIL MODIFIKASI. JURUSAN TEKNIK MESIN PROGRAM STUDI TEKNIK 
MESIN POLITEKNIK NEGERI

MANADO.

Putera, P., Intan, A., Mustaqim, F., \&

Ramadhan, P. (2019). Rancang

Bangun Mesin Pengupas Sabut Kelapa (Design of Coconut Fiber Separator Machine). Agroteknika, 2(1), 31-40. https://doi.org/10.32530/agtk.v2i1.31

Sulastri, Y., Widyasari, R., \& Kurniawan, H. (2018). Peningkatan Kualitas Gula Semut melalui Introduksi Mesin Pengaduk di Desa Kekait Kecamatan Gunung Sari Provinsi Nusa Tenggara Barat. Prosiding Konferensi Nasional Pengabdian Kepada Masyarakat Dan Corporate Social Responsibility (PKMCSR), 1, 530-536. 